\title{
DISTRIBUTION \\ OF CHARA BRAUNII GMELLIN 1826 (CHAROPHYTA) IN POLAND
}

\author{
JACEK URBANIAK \\ Department of Botany and Plant Ecology \\ Wrocław University of Environmental and Life Sciences \\ Pl. Grunwaldzki 24a, 50-363 Wrocław, Poland \\ e-mail: urbaniak@biol.uni.wroc.pl
}

(Received: May 22, 2006. Accepted: May 15, 2007)

\begin{abstract}
The distribution and ecology of Chara braunii Gmellin 1826 in Poland is described, based on herbaria collections, literature data and own investigations. Maps showing the distribution of $C h$. braunii are presented, as well as a list of localities with brief descriptions of the habitats. Additionally, some remarks on the distribution limit in the northern hemisphere are given.
\end{abstract}

KEY WORDS: Chara braunii, charophyta, charceae, algae, distribution, fish ponds, ecology, Poland.

\section{INTRODUCTION}

Chara braunii (Chara coronata) is the only one of several ecorticated species of the genus Chara occurring in Europe (Krause 1997) and the only species without cortication known from Poland.

Fish ponds are in Poland the only known sites where Chara braunii can be found, and where Ch. braunii sometimes build a community: Charetum coronatae Corillion 1957 with $C h$. braunii as a characteristic species. Almost all the presently known localities of $C h$. braunii have been found in southern Poland (southern Wielkopolska Lowland, Lower and Upper Silesia, Sandomierska Valley and Lublin Upland), where fish ponds are relatively common. According to Dąmbska (1964, 1966), Karczmarz (1966), Tomaszewicz (1979), Podbielkowski and Tomaszewicz (1996), Pukacz and Pełechaty (2004), Ch. braunii has in Poland a northern distribution limit in Northern Hemisphere. However Corillion (1957), Wood and Imahori (1965) show that $C h$. braunii is a cosmopolitan species widely distributed all over the World between $65^{\circ} \mathrm{N}$, and $35^{\circ} \mathrm{S}$. The main reason for these contradictory positions seems to be a poor investigation status of the past and present occurrence of $C h$. braunii in Poland. This was probably the reason for which $C h$. braunii has been placed on a "red" list of endangered algae in Poland in the category "indeterminate" (Siemińska 1992).

So the main aim of this study was to present the details of the distribution of Ch. braunii in Poland, and to compare it with their distribution limit in Europe, especially in the northern hemisphere. Additional some ecological aspects of their occurrence in Poland are presented.

\section{MATERIAL AND METHODS}

The maps of the distribution of Chara braunii in Poland and Europe were prepared on the basis field investigations done in 2003-2005, literature data and herbarium collections. I have examined the collections of charophytes from the following herbaria (acronyms according to Holmgren and Holmgren 1998) and private collections: Izabela Dąmbska Collection placed in Department of Hydrobiology, Adam Mickiewicz University, Poznań (I.D.); Museum of Natural History, University of Wrocław, Wrocław (WRSL, BRSL); Staatlichen Museum für Naturkunde, Görlitz (GLM); author's own collection placed in Department of Botany and Plant Ecology, Wrocław (J.U.). Additional material of European charophytes from Scandinavia based on own data and herbaria collections: Botanical $\mathrm{Mu}-$ sem, Lund University, Lund (L); Natural History Museum, Stockholm (S); Botanical Museum, Umeĺ (UM); Botanical Museum, Uppsala (U), have been added by Irmgard Blindow (Greifswald University, Germany). The determination of the specimens has been done by J. Urbaniak and I. Blindow based on Krause (1997).

The $10 \times 10 \mathrm{~km}$ ATPOL grid square system was used for the preparation of the distribution map in Poland and for the arrangement of lists of localities. For every locality in the list, the following data are presented: name or locality of the pond, the coordinates of the locality in the ATPOL grid system (Zając 1978), the collectors name and literature data.

The geographical distribution in Europe is based on material found in herbaria (listed above) and literature (Migula 1897; Corillion 1957; Langangen 1974; Hollerbach and Pala- 
mar-Mordvinceva 1991; Palamar-Mordvinceva and Tsarenko 2004; Compére 1992; Bruinsma et al. 1998; Cambra et al. 1998; Langangen et al. 2002; Zhakova 2003; Borisova 2005).

\section{RESULTS}

\section{Description of the species}

The plant is small to medium size, robust, fresh green to brownish green when found in the muddy bottom; transparent and richly branched. Plants are entirely ecorticate (Fig. 1). The main axis slender up to $1200 \mu \mathrm{m}$ in diameter. The stipulodes occur in a single whorl and are well developed. Branchlets 6-10 in a whorl, straight and occasionally incurved; segments $4-6$, the last one often reduced with 1 or more small end cells forming tiny terminal corona (Fig. 2). Bracteoles slightly longer as the oospore. The species is monoecious and richly fertile; oogonia are situated above the antheridia. The oospore is dark brown or black; membrane smooth to slightly granular (Figs 3 and 4).

\section{General distribution}

As may be seen in the Table 1, Chara braunii is one of the 33 different species of the genus Chara that can be found in Poland. According to Corillion (1957) and Wood, Imahori (1965) who summarized the world and European distribution of charophytes, Ch. braunii belongs to cosmopolitan species. In the southern part of Europe, the species can bee found in Greece, Albania and the Iberian Peninsu1a. The species is known from Asia: (Siberia, Kazakhstan, India, Pakistan, Japan, China, Philipines and Indonesia (Isle Lombock - maximal altitude $2400 \mathrm{~m}$ a. s. 1.) (Braun and Nordstedt 1882; Corillion 1957; Pal et al. 1962; Wood and Imahori 1965; Imahori 1954; Fushan and Yaoying 1994; Sviridenko 2000); Australia and New Zeland (Zaneveld 1940; Corillion 1957), North and South America (Co- rillion 1957; Wood and Imahori 1965), Africa (Corillion 1957) and Saudii Arabia (Hussain and Khoja 1999).

\section{The distribution in Poland}

The distribution of Chara braunii in Poland is presented on Figure 5.

\section{LIST OF LOCALITIES}

AD grid square: Prov. Lubuskie. 74 - Tuplice, fish pond (Pukacz and Pełechaty 2004).

AE grid square: Prov. Dolnośląskie. 79 - Podgórzyn near Jelenia Góra, fish pond (Schröder 1928).

BD grid square: Prov. Dolnośląskie. 98 - Radziądz, fish pond "Jeleni" (Schröder 1928).

BE grid square: Prov. Dolnośląskie. 08 - Żmigród, fish pond "Kogut" (Dąmbska 1963). 21 - Goliszów, pond near the village (Dąmbska 1966). 22 - Niedźwiedzice, fish pond nr. 17, leg. I. Dąmbska, 1963 (I.D.); Niedźwiedzice, fish pond nr. 6, leg. I. Dambska, 1963 (I.D.). 23 - Mała Raszowa pond nr. 7, leg. I. Dambska, 1963 (I.D.). 29 - Trzebnica, pond leg. B. Schröder, 1896 (GLM).

CD grid square: Prov. Dolnośląskie. 91 - Stawno, fish pond "Słoneczny", leg. I. Dambska, 1961 (I.D.); Stawno, fish pond "Jezuicki", leg. I. Dambska, 1961 (I.D.); Ruda Milicka, fish pond "Słupicki”, leg. I. Dambska, 1961 (I.D.); Ruda Milicka, fish pond "Jaskółczy" (Dąmbska 1963); Ruda Milicka, fish pond "Jaskółczy", leg. J. Urbaniak, 2003 (J.U.); Ruda Milicka, fish pond "Jaskółczy", leg. J. Urbaniak and K. Kuriata, 2005 (J.U.). 92 - Gądkowice, fish pond "Szałwia", leg. K. Kuriata, 2005 (J.U.); Gądkowice, fish pond "Jasny Dolny”, leg. K. Kuriata, 2005 (J.U.). 94 - Dębnica, fish pond "Dębnicki Duży”, leg. I. Dambska, 1964 (I.D.); Dębnica, fish pond "zimochów", leg. I. Dambska, 1964 (I.D.).

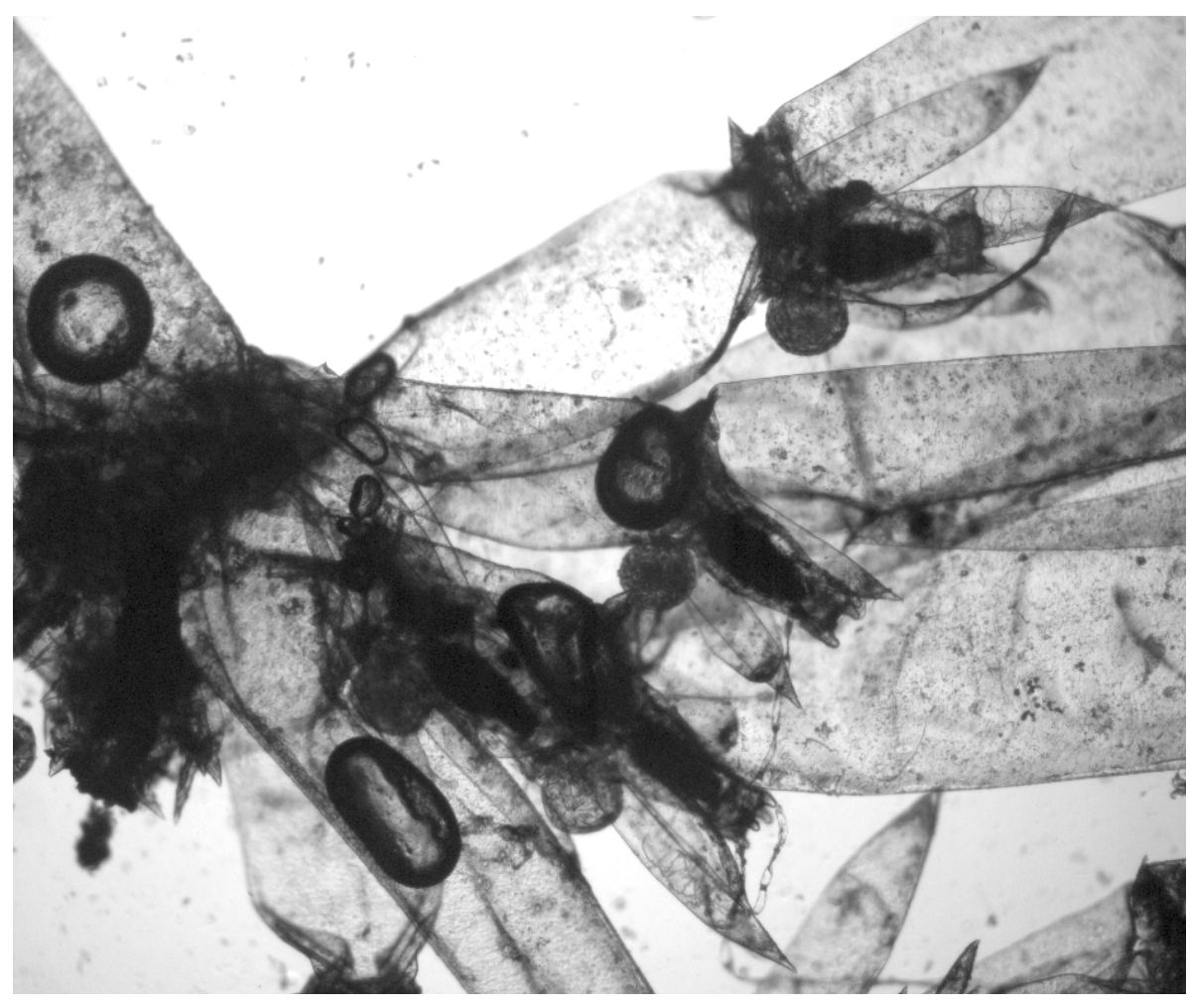

Fig. 1. Ecorticated branchlet with oogonia and antheridia of Chara braunii. 


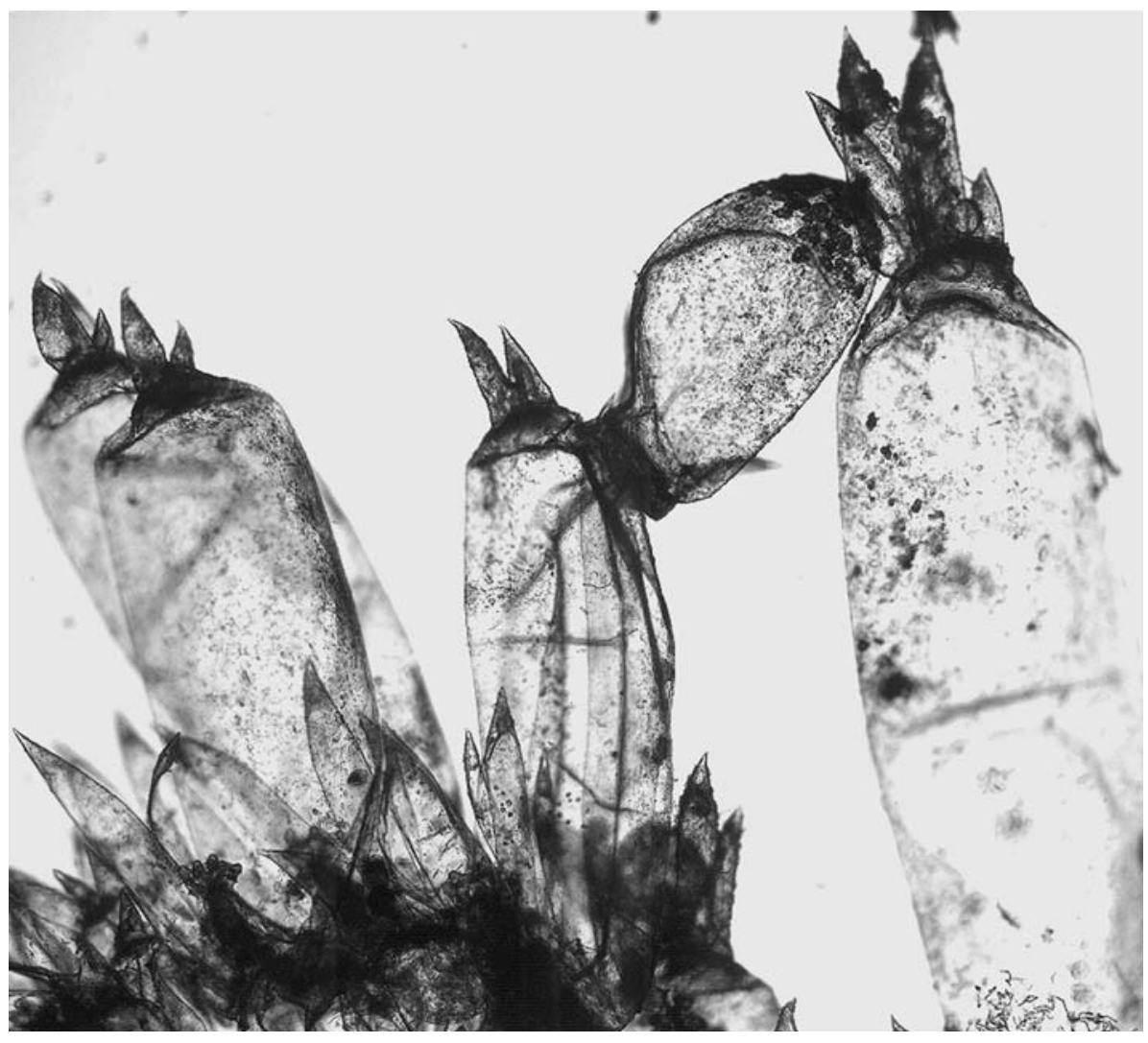

Fig. 2. The last reduced segment of branchlet forming tiny terminal corona.

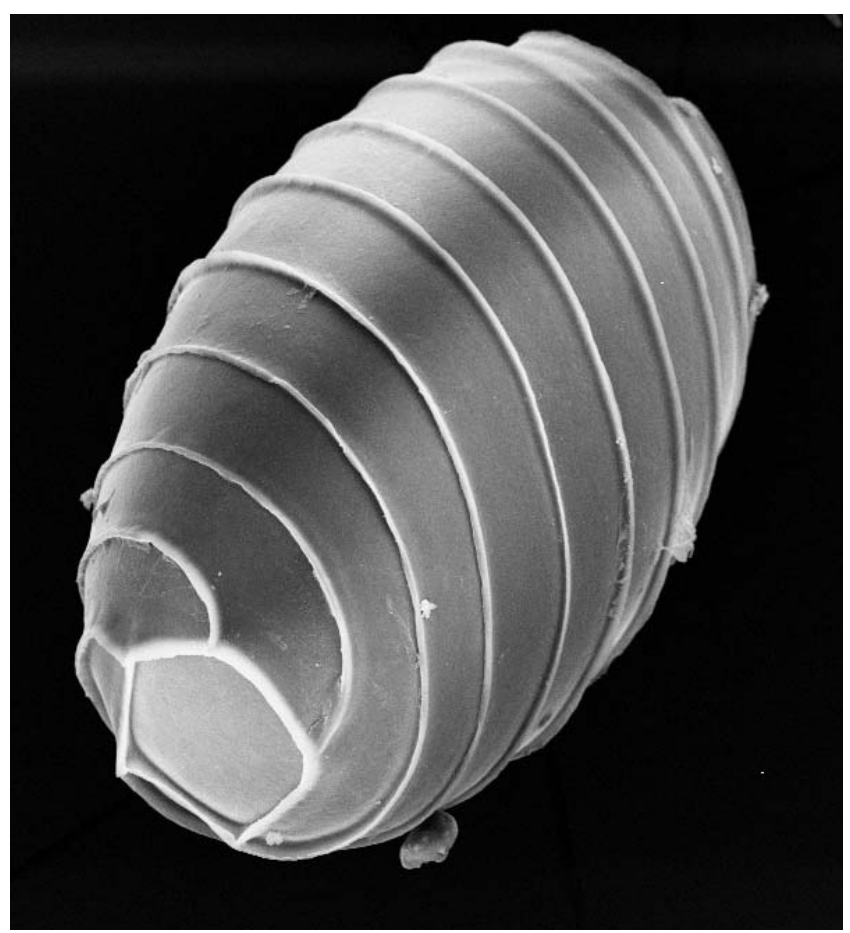

Fig. 3. Oospore of Chara braunii.

CE grid square: Prov. Dolnośląskie. 21 - Krośnice, fish pond "Wrzosowy" (Schröder 1928); Krośnice, fish pond "Wrzosowy", leg. I. Dambska, 1961 (I.D.); pond near Krośnice, (Schröder 1926; Schröder 1928). Prov. Opolskie. 86 Marszałki, pond "Marszałek", leg. I. Dambska, 1963 (I.D.).

CF grid square: Prov. Śląskie. 67 - Racibórz (Schröder 1926); 69 - Rybnik, fish pond "Młotek", leg. W. Migula, 1886 (WRSL). 78 - Jastrzębie Zdrój (Schröder 1926). 79 Połomia, pond, leg. W. Migula, 1886 (WRSL); Połomia (Schröder 1926); Żory (Schröder 1926).
DF grid square: Prov. Śląskie. 72 - Pszczyna (Schröder 1926). 76 - Zator, fish pond south of the fish farm "Przyręb" near Zator, leg. I. Dambska, 1963 (I.D.); Zator, fish pond in the fish farm "Bugaj", leg. I. Dambska, 1963 (I.D.). 81 - Gołysz, fish pond "Wyszni VIII", leg. I. Dambska, 1960 (I.D.); Gołysz, fish pond "Byczek Wielki", leg. I. Dambska, 1960 (I.D.); Gołysz, fish pond "Wyszni VI", leg. I. Dambska, 1960 (I.D.); Gołysz, fish pond "Młyński”, leg. I. Dambska, 1960 (I.D.); Gołysz fish pond "Okrągły Dolny", leg. I. Dambska, 1960 (I. D); Gołysz, fish pond "Bażyniec Dolny”, leg. I. Dambska, 1960 (I.D.); Ochaby, fish pond "Społeczny", leg. I. Dambska, 1960 (I.D.); Ochaby, fish pond "Odyniec, Rakowski?" leg. I. Dambska, 1960 (I.D.); Ochaby, fish pond "Rakowski", leg. I. Dambska, 1960 (I.D.); Ochaby, fish pond "Olszyniak", leg. I. Dambska, 1960 (I.D.); Ochaby, fish pond "Szyszkowski", leg. I. Dambska, 1960 (I.D.); Ochaby, fish pond "Karaś", leg. I. Dambska, 1960 (I.D.). 82 - Landek, fish pond "Staw Księżok Mały I", leg. I. Dambska, 1960 (I.D.); Landek, fish pond "Feruga", leg. I. Dambska, 1960 (I.D.); Landek, fish pond "Zabrzeski", leg. I. Dambska, 1960 (I.D.).

DF grid square: Prov. Małopolskie. 69 - Podgórze near Kraków leg. (?) 18. (WRSL).

FF grid square: Prov. Podkarpackie. 02 - Stale, fish pond in forestry "Stale". (Karczmarz et al. 1974). 03 - Grębów, pond, leg. I. Dambska, 1964 (I.D.). 60 - Pustynia, pond (Dąmbska 1966).

GE grid square: Prov. Lubelskie. 70 - Drozdówka, pond (Karczmarz 1966).

\section{DISCUSSION}

Based on the distribution map (Fig. 5), Chara braunii has been found only in the southern part of Poland, in specific 

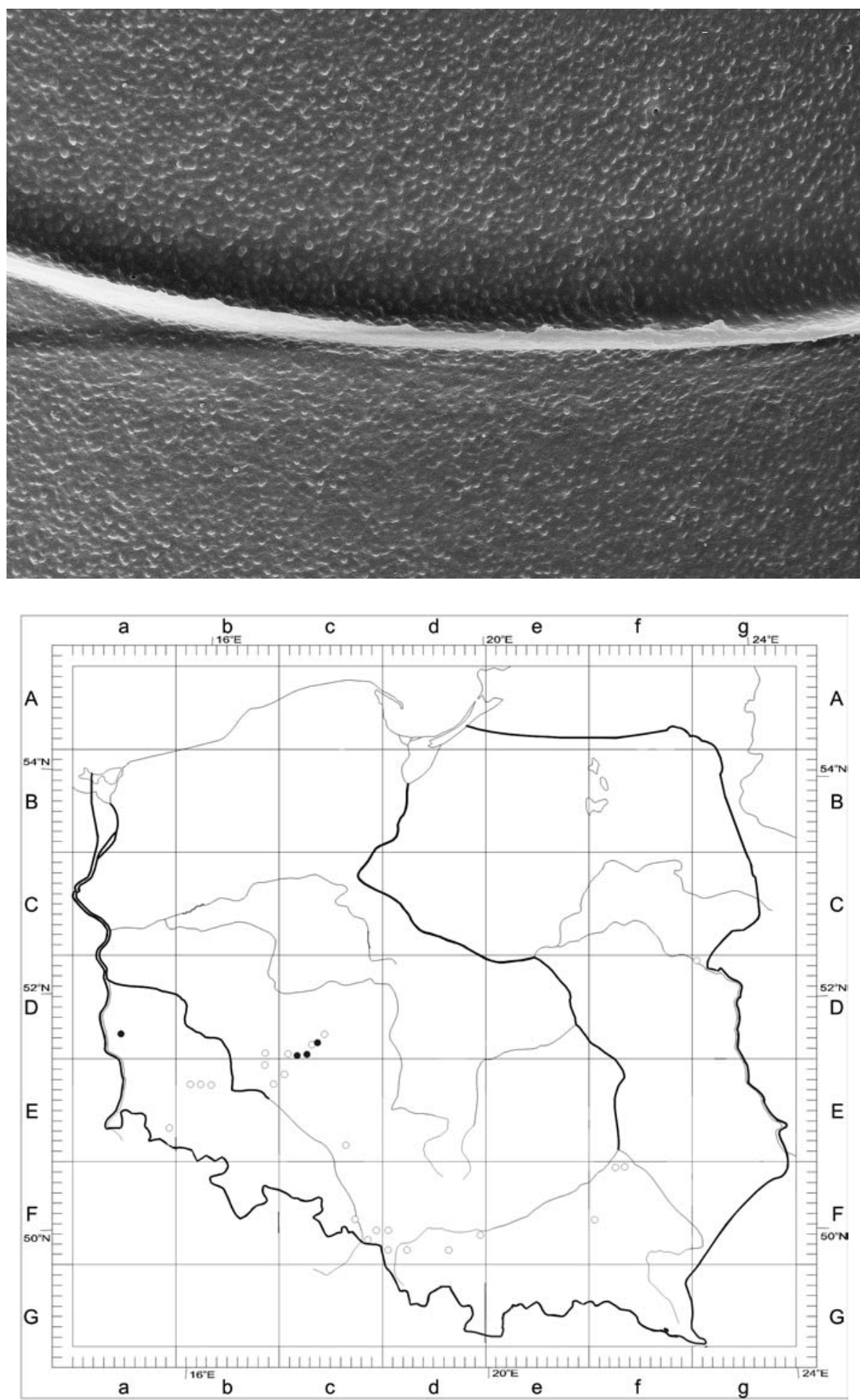

Fig. 4. Granular ornamentation of the oospore wall of Chara braunii.
Fig. 5. Distribution of Chara braunii Gmellin 1826 in Poland.

$\bigcirc$ - locality from literature or herbarium not confirmed; $\bullet$ - extant locality ecosystems like fish ponds. In separate localities in Lower Silesia the species has been refound by the author almost 40 years later, during field investigations. Schröder (1928) reported Ch. braunii firstly in the fish pond "Wrzosowy" near the village of Krośnice. In the same locality, I. Dąmbska refound Ch. braunii in 1961. In 1962 Ch. braunii grew in "Jaskółczy" pond in shallow water (Dąmbska 1963). In 2003 and 2005 it was found again in a few places in very shallow water in a muddy bottom by the author. From the localities in Goliszów and Podgórzyn near Jelenia Góra, $C h$. braunii has probably disappeared. Special investigations were done last years in order to find $C h$. braunii on this site, but without success. It is unknown if $C h$. braunii still occurs in fish pond complexes near Rybnik, Racibórz, Gołysz or Ochaby, where W. Migula and later I. Dąmbska has often noticed the species. It can be expected, that the species can be still be found there.

\section{The specific of fish pond habitats}

Usually, in Man-made fish ponds, the water is mostly shallow (0.5-2.0 m depth), turbid, heavily eutrophicated and rich in nutrients $-\mathrm{N}, \mathrm{P}, \mathrm{K}$ because of fish feeding. The water is generally alkaline and rich in calcium (because of liming - a common practice in the fish ponds), which are the reasons why charophyte flora, however scarce, can exist there. $C h$. braunii have never been found in Poland in 
TABLE 1. The charophyte species of Poland and neighboring countries. Species name after Blümel and Raabe (2004).

\begin{tabular}{|c|c|c|c|c|c|c|c|c|c|}
\hline \multirow[b]{3}{*}{ Species } & \multicolumn{9}{|c|}{ State } \\
\hline & \multirow[b]{2}{*}{$\begin{array}{l}\widetilde{\Xi} \\
\stackrel{\Xi}{0} \\
\varrho\end{array}$} & \multirow[b]{2}{*}{ 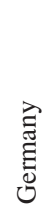 } & \multicolumn{3}{|c|}{ Baltic states } & \multicolumn{4}{|c|}{ Scandinavia } \\
\hline & & & 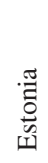 & 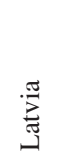 & 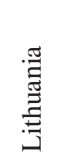 & 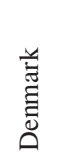 & $\begin{array}{l}\text { ते } \\
\text { Z }\end{array}$ & 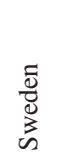 & 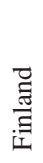 \\
\hline Chara aspera Willdenow 1809 & + & + & + & + & + & + & + & + & + \\
\hline Chara baltica Bruzelius 1824 & + & + & + & + & + & + & + & + & + \\
\hline Chara baueri A. Braun 1847 & & + & & & & & + & $+1)$ & \\
\hline Chara braunii C.C. Gmelin 1826 & + & + & & & & & + & + & + \\
\hline Chara canescens Loiseleur-Deslongchamps 1810 & + & + & + & + & + & + & + & + & + \\
\hline Chara crassicaulis (Schleicher ex A. Braun 1834) Kützing 1857 2) & + & 2) & & & & & & & \\
\hline Chara connivens Salzmann ex A. Braun 1835 & $+1) 3)$ & + & + & $++^{3)}$ & $+1)$ & & & + & \\
\hline Chara contraria A. Braun ex Kützing 1845 & + & + & + & + & + & + & + & + & + \\
\hline Chara denudata A. Braun 1847 & & + & & & & & & & \\
\hline Chara filiformis Hertzsch 1855 & + & + & & + & & $+3)$ & & + & \\
\hline Chara globularis Thuillier 1799 & + & + & & + & + & + & + & + & + \\
\hline Chara hispida Linnaeus 1753 & + & + & & + & & + & + & + & \\
\hline Chara horrida Wahlstedt 1862 & & + & + & & & + & & + & + \\
\hline Chara intermedia A. Braun 1859 in Braun, Rabenhorst et Sitzenberger 1857-1878 & + & + & & + & & $+3)$ & + & + & + \\
\hline Chara polyacantha A. Braun 1859 in Braun, Rabenhorst et Sitzenberger 1857-1878 & + & + & & & & + & & + & \\
\hline Chara rudis (A. Braun 1857) in Leonhardi 1864 & + & + & & + & & + & + & + & \\
\hline Chara strigosa A. Braun 1847 & + & + & + & + & & & + & + & + \\
\hline Chara tenuispina A. Braun 1835 & + & + & & & & & & & \\
\hline Chara tomentosa Linnaeus 1753 & + & + & + & + & & + & + & + & + \\
\hline Chara virgata Kützing 1843 & + & + & & + & & + & + & + & + \\
\hline Chara vulgaris Linnaeus 1753 & + & + & & + & + & + & + & + & \\
\hline Lamprothamnium hansenii (Sonder 1890) Corillion 1957 & & + & & & & & & & \\
\hline Lamprothamnium papulosum (Wallroth 1833) J. Groves 1916 & & + & & & & + & + & + & \\
\hline Lamprothamnium sonderi Garniel 2003 & & + & & & & & & & \\
\hline Lychnothamnus barbatus (Meyen 1827) Leonhardi 1864 & + & + & & & + & & & & \\
\hline Nitella capillaris (Krocker 1814) J. Groves et Bullock-Webster 1920 & + & + & & + & & & + & + & + \\
\hline Nitella confervacea (Brébisson 1849) A. Braun ex Leonhardi 1863 & + & + & & & & + & & + & \\
\hline Nitella flexilis (Linnaeus 1753) C.A. Agardh 1824 & + & + & & + & & + & + & + & + \\
\hline Nitella gracilis (J.E. Smith 1810) C.A. Agardh 1824 & + & + & & + & & + & + & + & + \\
\hline Nitella hyalina (De Candolle in Lamarck et De Candolle 1815) C.A. Agardh 1824 & & + & & & & & & & + \\
\hline Nitella mucronata (A. Braun 1834) Miquell in van Hall 1840 & + & + & & + & & + & + & + & \\
\hline Nitella opaca (Bruzelius 1824) C.A. Agardh 1824 & + & + & & + & & + & + & + & + \\
\hline Nitella syncarpa (Thuillier 1799) Chevallier 1827 & + & + & & + & & & & + & \\
\hline Nitella tenuissima (Desvaux 1809) Kützing 1843 & + & + & & + & + & & & + & \\
\hline Nitella translucens (Persoon 1807) C.A. Agardh 1824 & + & + & & + & & + & + & + & \\
\hline Nitella wahlbergiana Wallman 1853 & & & & & & & & + & + \\
\hline Nitellopsis obtusa (Desvaux in Loiseleur-Deslongchamps 1809) J. Groves 1919 & + & + & & + & + & + & & + & + \\
\hline Tolypella canadensis Sawa 1973 & & & & & & & + & + & + \\
\hline Tolypella glomerata (Desvaux in Loiseleur-Deslongchamps 1810) Leonhardi 1863 & + & + & & & & + & + & + & \\
\hline Tolypella intricata (Trentepohl ex Roth 1797) Leonhardi 1863 & + & + & & & & + & & + & \\
\hline Tolypella nidifica (O.F. Müller 1778) Leonhardi 1863 & + & + & + & + & + & + & + & + & + \\
\hline Tolypella normaniana Norstedt 1868 & & & & & & & + & & \\
\hline Tolypella prolifera (Ziz ex A. Braun 1834) Leonhardi 1863 & + & + & + & + & + & & & & \\
\hline Total numbers of the species & 33 & 39 & 10 & 25 & 12 & 25 & 25 & 35 & 20 \\
\hline
\end{tabular}

${ }^{1)}$ species probably extinct; ${ }^{2}$ in Germany species included into C. vulgaris; ${ }^{3)}$ only old historical records known

The table was prepared based the herbarium collections, literature data and personal communication as follow: Poland (I. Dąmbska Collection - Dept. of Hydrobiology Adam Mickiewicz University, KRA, KRAM, WRSL, LBL, author own collection), Germany (Schmidt et. al. 1996; C. Blüemel, I. Blindow, A. Doege, U. Raabe, K. van de Weyer - pers comm.), Lithuania (Balevicius, Ladyga 1992, Z. Sineviciene - pers. comm.), Latvia (Z. Dekere, E. Zviedre pers. comm.), Estonia (G. Martin, K. Torn - pers. comm.), Denmark (C, Olsen 1944, J. Anderson, L. Mathiesen - pers. comm.), Norway (Langangen 1974), Sweden (Blindow, Krause 1990, Gärdenfors 2005, I. Blindow - pers. comm.), Finland (H. Langangen et al. 2002; M. Koistinen, R. Munsterhjelm pers. comm.). Schubert, Blindow (2003). 
TABLE 2. Physico-chemical characteristic of water from the localities of Chara braunii Gmellin 1826.

\begin{tabular}{|c|c|c|c|c|c|}
\hline Country & Finland & Norway & Poland & Sweden & Russia \\
\hline Literature cited & $\begin{array}{l}\text { Langangen et. al. } \\
(2002)\end{array}$ & Langangen (1974) & $\begin{array}{l}\text { Dąmbska (1964, 1966); } \\
\text { Pukacz and Pełechaty } \\
\text { (2004) } \\
\text { J. Urbaniak (this work) }\end{array}$ & $\begin{array}{l}\text { I. Blindow (pers. } \\
\text { comm.) }\end{array}$ & Zhakova (2003) \\
\hline Salinity (\%o) & $\begin{array}{l}\text { Fresh and brackish } \\
\text { water }(0-1)\end{array}$ & $\begin{array}{l}\text { Fresh and brackish } \\
\text { water }\end{array}$ & Fresh water & $\begin{array}{l}\text { Fresh }(\text { Extinct }) \text { and } \\
\text { brackish water }(0-3)\end{array}$ & $\begin{array}{l}\text { Fresh and brackish } \\
\text { water }\end{array}$ \\
\hline Type of water ecosystem & $\begin{array}{l}\text { Baltic Sea, eutrophic } \\
\text { lakes, gently moving } \\
\text { rivers }\end{array}$ & $\begin{array}{l}\text { North Sea, Lobelia- } \\
\text { lakes, gently moving } \\
\text { rivers }\end{array}$ & $\begin{array}{l}\text { Fish ponds (eutrophic } \\
\text { water) }\end{array}$ & $\begin{array}{l}\text { Baltic Sea (Bothnian } \\
\text { Bay) }\end{array}$ & $\begin{array}{l}\text { Baltic Sea, eutrophic } \\
\text { lakes, Nava mouth } \\
\text { (eutrophic water) }\end{array}$ \\
\hline Type of bottom sediment & Gravel, clay, sand, silt & & Mud, clay & & \\
\hline $\mathrm{pH}$ & & $6.6-8.6$ & $6.8-8.2$ & & \\
\hline Conductivity $(\mu S)$ & & $10-200$ & $320-370$ & & \\
\hline $\mathrm{Ca}(\mathrm{mg} / \mathrm{l})$ & & $7-13$ & $43-57$ & & $15.6-21.5$ \\
\hline $\mathrm{Mg}(\mathrm{mg} / \mathrm{l})$ & & & $7.5-1.2$ & & $14.2-18.2$ \\
\hline $\mathrm{K}(\mathrm{mg} / \mathrm{l})$ & & & $5.5-9.8$ & & $8.2-25$ \\
\hline $\mathrm{Na}(\mathrm{mg} / \mathrm{l})$ & & & & & $18.0-30$ \\
\hline $\mathrm{Cl}(\mathrm{mg} / \mathrm{l})$ & & $0-1000$ & & & \\
\hline
\end{tabular}

the peat pits, probably because of the lower $\mathrm{pH}$ value of water.

Recently, Ch. braunii in fish ponds "Jaskółczy" and "Jasny Dolny" has been found on a soft bottom (mud). The records were from shallow or very shallow water of 0.2-0.7 $\mathrm{m}$. This seems to be confirmed by the Polish herbaria collections. All specimens originate from shallow water $(0.1-$ $0.5 \mathrm{~m}$ ), but one plant was found at $1 \mathrm{~m}$ depth; almost all were found mainly on are muddy bottom. According to Hollerbach and Krasavina (1983) Ch. braunii seems to be a warm water species, which may explain its restriction to shallow water. The species can be found in a euphotic zone - in the upper illuminated zone of aquatic ecosystem which in fish ponds is very shallow, so the maximum depth observed by different authors was about $1.5 \mathrm{~m}$. The other physico-chemical data from the recently found localities by the author are presented in Table 2.

The intensity of management in fish ponds seems to be an important reason for the occurrence of Ch. braunii. In extensive (pond) aquaculture, fish growth is limited by the availability of natural food supplies, commonly zooplankton feeding on pelagic algae or benthic animals. The photosynthetical production can be increased by fertilizing the pond water with artificial fertilizer (Brunson et al. 1999). In intensive (closed - circulation) aquaculture fish production can be increased at will, as long as sufficient oxygen, fresh water and fish food rich in proteins are provided. In the intensive farming, with the high fish density higher plants and charophyte flora are scarce or mostly absent and the direct reason seems to be the high turbidity and poor light availability. Both are proposed as limiting factors for charophytes occurrence (Blindow 1992), and probably for
Ch. braunii, which have been observed by the author. During the field work, $C h$. braunii and any other charophytes have not been found in fish ponds with intensive fish feeding. All findings (past and present records) have been made in shallow water near the shore line, in ponds with extensive aquaculture or used only periodically. Similarly, Corillion (1957) found Ch. braunii near the shore line in ponds which periodically become dry on the sandy or muddy bottom in shallow or very shallow water $(0.05-1.0 \mathrm{~m})$, with the high availability of light in places that are free from the plants and filamentous algae competition. It is possible, that the drying periods can play an important role in the biology of Ch. braunii, however experimental studies are needed to better understand this problem.

The findings of Ch. braunii in southern Poland only in fish ponds may have suggested (Dąmbska 1964, 1966) that this species is restricted only to this type of ecosystem, but this is not true. The species has been found in Scandinavia (Sweden, Norway, Finland) and in Russia, mostly in eutrophic, low transparency water (lakes and slowly moving rivers) or near the shore line or in oligotropic lakes (lobelia lakes) in Norway (Langangen 1974) (Table 2). All recent records from Sweden are from the province Norrbotten the northernmost part of the Bothnian Bay in brackish water.

\section{The northern Europe distribution limit}

The results of this study (Figs 5 and 6) do not confirm the opinion that Chara braunii has in Poland the northern limit of its distribution (Dąmbska 1964; Pukacz and Pełechaty 2004). According to various authors, Ch. braunii belongs to the cosmopolitan species described by Wood and 


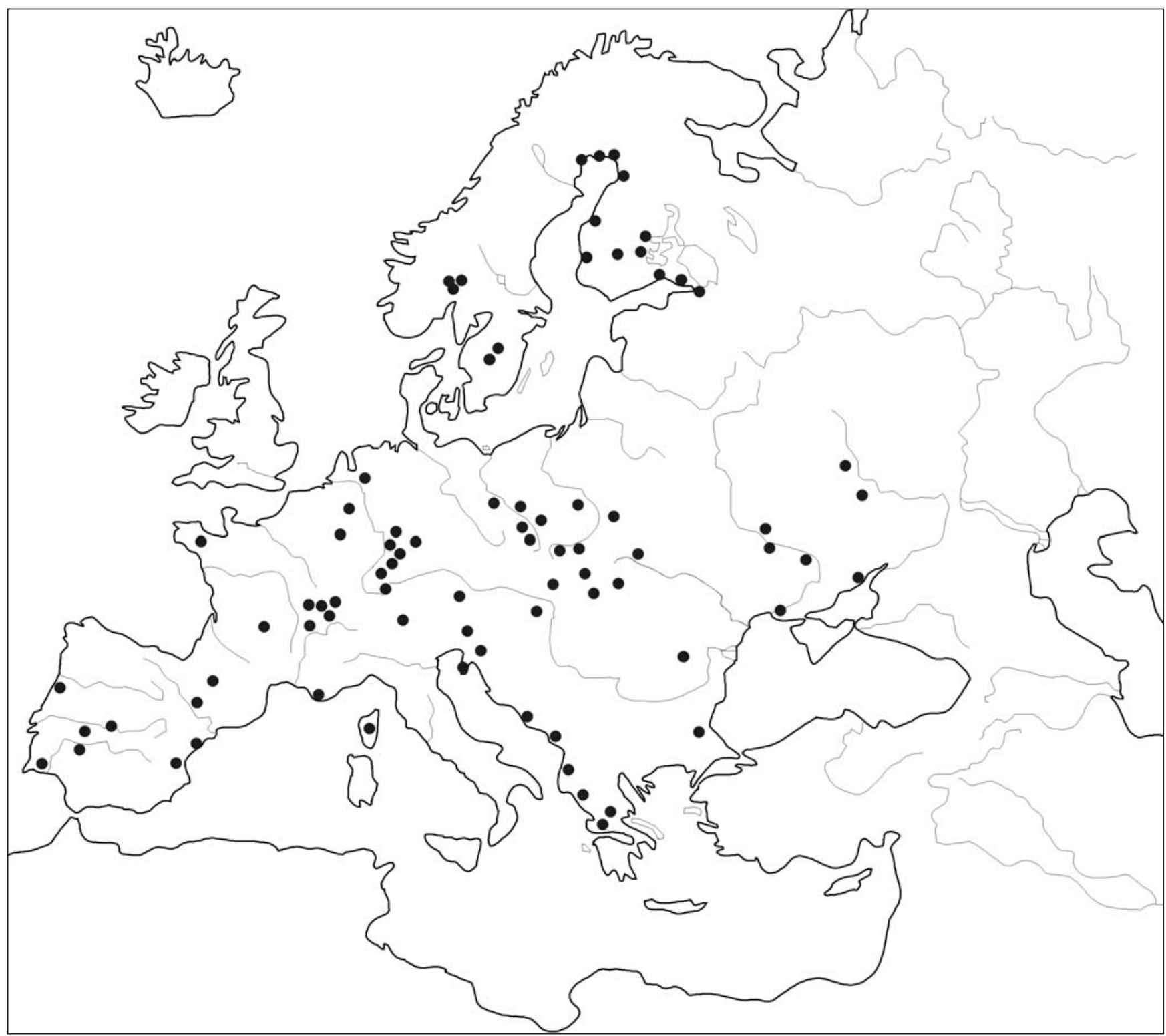

Fig. 6. Distribution of Chara braunii Gmellin 1826 in Europe based on herbarium, literature data and personal communication.

Imahori (1965) as a "weed" species, however rarely found in Europe. In Poland the species is known only from specific sites such as extensively used fish ponds in the southern part of the country, where the fish farms are common. The complete lack of data from central and northern Poland may reflect rather the lack of investigations (collection) than the real rarity of this species. Some of the as yet unrecorded and not unregistered $C h$. braunii sites, can be expected there as well as in the other Baltic States (Lithuania, Latvia and Estonia). The species richness of a particular region (country) is directly related to the number and activity of aquatic botanists and the tradition of charophyte investigations.

\section{ACKNOWLEDGEMENT}

I am grateful to all who contributed information about the occurrence of Chara braunii: Prof. L. Burhardt (Department of Hydrobiology, Adam Mickiewicz University, UAM) and especially for I. Blindow (Greifswald University).
This work was supported by the Wrocław University of Environmental and Life Sciences (project no. 313/GW/06). SEM pictures has been done in a Laboratory of Scanning Electron Microscopy at the Wrocław University of Environmental and Life Sciences.

\section{LITERATURE CITED}

BALEVICIUS K., LADYGA A. 1992. Lietuvos raudonoji knyga (The Red Data Book of Lithuania). Lithuanian Department of Environmental Conservancy, Vilnius.

BLINDOW I. 1992. Decline of charophytes during eutrophication: Comparison to angiosperms. Freshwater Biol. 28: 9-14.

BLINDOW I., KRAUSE W. 1990. Bestamningsnyckel för svenska kransalger (Key to the Swedish species of Charophyta). Svensk Bot. Tidskr. 84: 119-160.

BLÜMEL C., RAABE U. 2004. Vorlaufige Checkliste de Characeen Deutschlands. Rostocker Mereesbiologische Beiträge 13: 9-26.

BORISOVA E.V. 2005. Species composition and distribution of Charales in the Ukraine. Inter. J. Algae. 7 (1): 88-102. 
BRAUN A., NORDSTEDT C. F. O. 1882. Fragmente einer Monographie der Characeen. Nach den hinterlassenen Manuskripten A. Braun's herausgegeben von Dr. O. Nordstedt. Abh. Kgl. Akad. Wiss. Berlin. 221 pp. Verlag d. Kgl. Akad. Wiss., Berlin.

BRUINSMA J., KRAUSE W., NAT E., RAAM J. 1998. Determintietabel voor kranswieren in de Benelux. 101 pp. Stichting Jeugdbondsuitgeverij, Utrecht.

BRUNSON M.W., STONE N., HARGREAVES J. 1999. Fertilization of Fish Ponds. Southern Regional Aqauculture Center Publication 471: 1-4.

CAMBRA J., ÁLVAREZ-COBELAS M., ABOAL M. 1998. Lista Florística y bibliográfica de Iosclorófitos (chlorophyta) de la Península Ibérica, Islas Baleares e Islas Canarias. Listas de la flora y fauna de las agues continentals de la Peninsula Ibérica. Asociación Espańola de Limnologia 14, pp. 1-14.

COMPČRE P. 1992. Charophytes. Flore pratique des algues d'eau douce de Belgique. 4, pp. 1-77. Jardin Botanique National de Belgique, Meise.

CORILLION R. 1957. Les charophycées de France et d'Europe Occidentale. Travaux Lab. Bot. Fac. Sci. d'Angers. 499 pp. Reprint, Otto Koeltz Verlag, Koenigstein-Taurus 1972.

DĄMBSKA I. 1963. Nowe stanowiska ramienic (Charceae) w Polsce północno-zachodniej [New findings of stoneworts (Characeae) in Western and Northern part of Poland]. Bad. Fizjogr. Pol. Zach. 12: 259-364. (in Polish with English summary)

DAMBSKA I. 1964. Charophyta - ramienice [Charophytes - stoneworts]. Flora Słodkowodna Polski. 13, pp. 1-126. Państwowe Wydawnictwo Naukowe, Warszawa (in Polish).

DĄMBSKA I. 1966. Zbiorowiska ramienic Polski [Communities of Characeae in the area of Poland]. Pozn. Tow. Przyj. Nauk, Wydz. Mat. Przyr. Prace Kom. Biol. 31 (3): 1-75. (in Polish with English summary)

FUSHAN H., YAOYING L. 1994. Charophyta. Flora algarum sinicarum, aquae dulcis. 3, pp. 1-263. (in Chinese with English summary)

GÄRDENFORS U. 2005. (ed.), Rödliste arter i Svergie 2005. ArtDatabanken, SLU, Upsala.

HOLLERBACH M.M., KRASAVINA L.K. 1983. Opredelitel presnovodnyh vodoroslei SSSR. Harovye vodororosli - Charophyta [Determination key of freshwater species USSR. Stoneworts - Charophyta]. 14, pp. 1-189. Nauka, Leningrad (in Russian).

HOLLERBACH M.M., PALAMAR-MORDVINTSEVA G.M. 1991. Vyznachnik presnovodnyh vodoroslei Ukrainy. Harovye vodororosli (Charophyta). [Determination key of freshwater species of Ukraine. Stoneworts (Charophyta)]. 9, pp. 1-194. Naukova Dumka, Kiev. (in Ukrainian)

HOLMGREN P.K., HOLMGREN N.H. 1998. Index Herbariorum. New York Botanical Garden - onwards (continuously updated). http: //sciweb.nybg.org/science2/IndexHerbariorum.asp

HUSSAIN M.I., KHOJA T. M. 1999. Chara braunii (Charales, Charophyta) in an Arid Rainfed Waterbody, Saudi Arabia. Aust. J. Bot. 47: 427-436.

IMAHORI K. 1954. Ecology, phytogeography and taxonomy of the Japanese charophyta, Kanazawa University. 234 pp. Reprint, Otto Koeltz Science Publisher, Koenigstein 1977. (in Japanese with English summary)

KARCZMARZ K. 1966. Przyczynek do badań nad florą ramienic Lubelszczyzny (Polska Wschodnia), cz. III [Contribution to the charophyte flora of Lubelszczyzna region (Eastern Poland), part III]. Acta Soc. Bot. Pol. 35 (2): 265-271. (in Polish with French summary)

KARCZMARZ K., ŁUCZYCKA A., OCHYRA R. 1974. Materiały do flory ramienic środkowej i południowej Polski, cz 2.
[Contribution to the charophyte flora of Central and Southern Poland, part 2]. Acta Hydrobiol. 18 (2): 193-200. (in Polish with English summary)

KRAUSE W. 1997. Charales (Charophyceae). Süsswasserflora von Mitteleuropa. 18, pp. 1-202. Gustav Fisher Verlag.

LANGANGEN A. 1974. Ecology and distribution of Norwegian charophytes. Norwegian J. Bot. 21: 31-52.

LANGANGEN A., KOISTINEN M., BLINDOW I. 2002. The Charophytes of Finland. Mem. Soc. Fauna Flora Fennica. 78: 17-48.

MIGULA W. 1897. Die Characeen Deutschlands, Osterreichs und der Schweiz. In: L. RABENHORST (ed.), Kryptogamen Flora von Deutschlands, Osterreichs und der Schweiz. 5, pp. 1-765. Eduard Kummer Verlag, Leipzig.

OLSEN S. 1944. Danish Charophyta. Chorological, ecological and biological investigations. Konegl. Danske Vid. Selsk. Biol. Skr. 3: 1-240.

PAL B.P., KUNDU B.C., SUNDARALINGAM V.S., VENKATARAMAN G.S. 1962. Charophyta. 130 pp. Indian Council of Agricultural Research, New Delhi.

PALAMAR-MORDVINTSEVA G.M., TSARENKO P. 2004. Red list of Charales of the Ukraine. Inter. J. Algae. 6 (4): 305-318.

PODBIELKOWSKI Z., TOMASZEWICZ H. 1996. Zarys Hydrobotaniki [Hydrobotany]. 531 pp. Państwowe Wydawnictwo Naukowe, Warszawa, (in Polish)

PUKACZ A., PEŁECHATY M. 2004. Nowe stanowisko Chara braunii (Charophyceae) w Polsce [New locality of Chara braunii (Charophyceae) in Poland]. Fragm. Flor. Geobot. Polonica 11: 191-196. (in Polish with English summary)

SCHMIDT D., VAN WEYER K., KRAUSE W., KIES L., GARNIEL A., GEISSLER U., GUTOWSKI A., SAMIETZ R., SCHÜTZ W., VAHLE H.C., VÖGE M., WOLFF P., MELTZER A. 1996. Rote Liste der Armleuchteralgen (Charophyceae) Deutschlands, 2. Fassung, Stand: Februar 1995. Schriftenreihe für Vegetationskunde 28: 547-576.

SCHRÖDER B. 1926. Neue beitrage zur Schlesischen Characeenkunde. Abh. Naturf. Ges. Gorlitz. 29 (3): 52-61.

SCHRÖDER B. 1928. Weitere funde schlesischer Characeen. Jahresb. Schles. Ges. Vaterl. Cult. 100: 26-30.

SCHUBERT H., BLINDOW I. 2003 (red.), Charophytes of the Baltic Sea. Gantner Verlag, Ruggel.

SIEMIŃSKA J. 1992. Czerwona lista glonów zagrożonych w Polsce [Red list of threatend algae in Poland]. In: Zarzycki K., Wojewoda W., Heinrich Z. (eds), Lista roślin zagrożonych w Polsce [Red list of threatend plants in Poland]. 7-19 pp. Instytut Botaniki im. W. Szafera, Polska Akademia Nauk, Kraków. (in Polish with English summary)

SVIRIDENKO B.F. 2000. Flora and vegetation of Reserviors of north Kazkhstan. 196 pp. Omsk Pedagogical University, Omsk. (in Russian)

TOMASZEWICZ H. 1979. Roślinność wodna i szuwarowa Polski. Rozprawy Uniwersytetu Warszawskiego [Water and bulrush plants of Poland. Warsaw University Disertations]. 324 pp. Wydawnictwa Uniwersytetu Warszawskiego, Warszawa. (in Polish)

WOOD R.D., IMAHORI K. 1965. A revision of the Characeae. Monograph of the Characeae. 904 pp. J. Cramer Verlag, Weinheim.

ZAJĄC A. 1978. Atlas of distribution of vascular plants in Poland (ATPOL). Taxon 27: 481-484.

ZANEVELD J.S. 1940. The charophyta of Malaysia and adjacent countries. Blumea 4 (1): 1-224.

ZHAKOVA L.V. 2003. Chara braunii C.C. Gmel. 1826. In: Schubert H., Blindow I. (eds), Charophytes of the Baltic Sea. 64-69 pp. Gantner Verlag, Ruggel. 